\title{
Agents and Processes in Knowledge Creation and Management in Educational Organisations
}

\author{
Joaquín Gairín, David Rodríguez-Gómez and Carme Armengol \\ Department of Applied Pedagogy, Universitat Autonòma de Barcelona
}

Spain

\section{Introduction}

Today's society has enshrined knowledge and worker training as strategic elements in organisations, viewing individual and collective intellectual capital as one of the main resources available to them in achieving their mission. In this context, organisations are seeking new strategies that enable their employees to share experiences, impressions and knowledge, aware that what makes an organisation competitive is its ability to develop the human capital it has at its disposal.

Isolated professionals that interact solely with themselves or with their materials no longer make sense; rather what truly matters is the configuration of human groups that are in constant interaction through networks or communities. Therefore, it should come as no surprise that organisations are determinedly seeking how to foster collaborative processes and the development of the environments that facilitate them (Gairín, 2011).

Education professionals and school networks are an excellent tool to instigate improvements in the educational systems. These networks can be established between professionals at the same schools, between schools and education and social services from a same town, between educational and professional centres from different towns and communities or even between professionals from different countries.

The information and communication technologies can be an opportunity and a powerful weapon when setting up a new collaborative professional culture, which is so necessary in our day. First, they open up and improve the possibilities for collaboration, which is further enhanced with the implementation and gradual development of tools related to the concept of Web 2.0; secondly, when used properly, ICTs help to systematise the processes of knowledge exchange, creation and management that take place. The desirable knowledgebased organisation which not only stimulates the creation and management of knowledge but also fosters its transfer and support in diverse media is becoming more of a reality to us. The new forms of work based on the virtual network, such as virtual communities, remote networks and collaborative work environments thus fulfil their objective with the aid of technology, which becomes a fundamental tool for the exchange of information, knowledge, learning and experiences and for the creation of new knowledge.

Several studies and publications confirm that the establishment of networks and communities encourages knowledge creation and professional development processes (Aubusson et al., 2007; Dering, Cunningham \& Whitby, 2006; Kimmble \& Hildreth, 2005; 
Klein, Connel \& Meyer, 2005; Leinonen \& Järvelä, 2006; Jeon, Kim \& Koh, 2011; Ragachari, 2011, Schenkel \& Teigland, 2008; Usora et al, 2007; Wenger, 1999, Zang \& Watts, 2007).

"Among the chief reasons why communities of practice are efficient tools for knowledge generation and sharing is the fact that the most of a firm's competitive advantage is embedded in the intangible, tacit knowledge of its people and that competencies do not exist apart from the people who develop them" (Ardichvili, Page \& Wentling, 2003, p. 65).

From a relational approach, knowledge is understood as socially constructed resource and, therefore, Knowledge Creation and Management (henceforth KCM) processes should be concentrated on social relations and/or professionals who connect the different agents involved. In this sense, it is obvious that organisational solutions that foster those relations, such as communities of practice (CoPs), are an interesting way of promoting KCM.

Over and above the use of CoPs, the development of KCM strategies entails the theoretical and practical command of processes for measuring, creating and disseminating individual and collective knowledge, and the participation of different agents with a clear definition of responsibilities and functions which ensure the proper development of these processes and, therefore, the success of the KCM strategy.

The handful of KCM studies and experiences in the field of education (Petrides \& Nguyen, 2006; Sallis \& Jones, 2002) which provide theoretical and practical knowledge on the processes and agents of KCM are the motivation behind this article, ${ }^{1}$ which aims to provide practical answers for the development of KCM processes in educational organisations.

In this chapter, we shall note the requirements and benefits of collaborative work among professionals, develop a theoretical survey of the leading processes and agents traditionally linked to KCM processes based on Communities of Practice (henceforth CoPs) and, based on the research, outline a proposal on the essential roles, functions and processes for the design, development and evaluation of any KCM strategy in educational organisations.

\section{Collaboration among professionals}

Desirable professional development cannot isolate itself from a consideration of the workplace contexts in which it takes place. The goal is to extend beyond the individual action that has traditionally characterised professional interventions and consider the organisation where these individuals act and their context of action. Taking on institutional commitments to professionalisation, fostering structures for cooperative work and generating processes of internal dynamisation is a personal and institutional challenge, but they are impossible without a change in today's macro- and micro-structural conditions which always exist and in which professionals operate.

Cooperation among professionals is considered necessary in today's educational settings, since many of the existing problems cannot be resolved based on limited specialisation and instead require group thinking and teamwork. Likewise, professional action is not individual but group and coordinated if we think about broad intervention processes over time and in the variety of people affected. Collaborative work enables our knowledge to be enriched, expanded and compared in the quest for solutions to the problems posed by the

\footnotetext{
${ }^{1}$ This article is also based on the broader ACCELERA study (Rodríguez-Gómez, 2009; Gairín-Sallán \& Rodríguez-Gómez, 2010; Gairín-Sallán, Rodríguez-Gómez \& Armengol, 2010; Gairín, 2011), launched in 2003 by the EDO team (http://edo.uab.cat) and financed by the National RDI plan of the Spanish Ministry of Science and Technology (projects SEC2003-08366 and SEJ2007-67093/EDUC).
} 
reality around us. Likewise, we must act from or with institutional frameworks where the goal is to generate synergies and leave an embedded capacity related to strategies, procedures and positive attitudes towards change.

Collaboration among professionals is considered useful in that it helps to overcome the individualism to which professional activities often lead. In fact, collective work can help us to shift from one activity with others, to one activity in conjunction with others, a collaborative activity, and ultimately it can facilitate a community of interests and a shared culture. Collaboration boosts the creative potential of the resulting team, and the technology of the solutions that they adopt is more proven. We can also mention higher performance in human resources and how they make more profitable use of the material and functional resources available to them. Collaboration enables and challenges reflection on one's own activity, with connotations of personal, collective and institutional improvement. In fact, professional exchanges can broaden perspectives and improve ways of doing things, such as by augmenting the participants' professionalism. Duly channelled in the organisation's processes and results, collaboration provides the members of the organisation with the skill and experience already existing in the organisation and enables new members to integrate quickly and fully. Finally, collaboration strengthens collective activity and a view of organisations as communities of training and professional development.

Collaboration among professionals is considered possible, as denoted by the numerous examples and existing evidence. As proof we can cite the collaborative processes which are taking place in the world of education and internally encompass both the coordination of certain students' problems and the organisation and operation of teams of teachers, while externally they encompass associations of schools under the same organisational parameters, groups of schools in rural areas, associations of adult schools, networks of schools, associations between secondary schools and companies or between schools and universities, and collaborative actions promoted within broader contexts such as environmental plans, the City Educational Project and the Innova portal (www.portalinnova.org).

Our current models of social, cultural and economic functioning increasingly support collective undertakings and participatory processes. This is the result of not only living in democratic contexts but also the conviction that in complex settings like ours today innovation and change depend more on the outcome of a collective activity than on the existence of extraordinary individuals capable of motivating desires and overcoming difficulties by themselves.

As has been suggested, the creation of networks and communities fosters collaboration among professions and processes of knowledge creation and professional development, thus justifying many organisations' interest in fostering social and professional ties among their members. We can find references in this vein in professional Communities of Practice (henceforth CoPs).

Many authors (Bolam et al., 2005, Collison \& Parcell, 2003, Dalkir, 2005, Hardon, 2005, Hargreaves \& Giles, 2003, Milton, 2005) use the terms 'network' and 'community' synonymously. However, it is important to point out that some experts distinguish clearly between the two (Cummings \& Van Zee, 2005, Despres \& Chauvel, 2000, Müller-Prothmann, 2006, Wenger \& Snyder, 2000), basing this distinction on the boundaries, from the standpoint of social interaction and belonging, which characterise Communities of Practice (henceforth $\mathrm{CoP})$ yet do not exist in networks. Table 1 outlines some of the characteristics which can help us to differentiate between terms similar to 'community of practice'. 


\begin{tabular}{|c|c|c|c|c|}
\hline $\begin{array}{l}\text { Kind of } \\
\text { Organisation }\end{array}$ & Purpose & Membership & Cohesion & Duration \\
\hline $\begin{array}{l}\text { Community } \\
\text { of Practice }\end{array}$ & $\begin{array}{l}\text { Developing their } \\
\text { members' } \\
\text { capacities, } \\
\text { constructing and } \\
\text { exchanging } \\
\text { knowledge }\end{array}$ & Self-selection & $\begin{array}{l}\text { Passion, } \\
\text { commitment, } \\
\text { identification } \\
\text { with the group's } \\
\text { expert } \\
\text { knowledge }\end{array}$ & $\begin{array}{l}\text { Until the } \\
\text { interest in } \\
\text { maintaining } \\
\text { the community } \\
\text { disappears }\end{array}$ \\
\hline $\begin{array}{l}\text { Interest } \\
\text { group }\end{array}$ & $\begin{array}{l}\text { Sharing } \\
\text { knowledge, } \\
\text { learning, } \\
\text { creating } \\
\text { knowledge }\end{array}$ & $\begin{array}{l}\text { Voluntary, } \\
\text { open } \\
\text { involvement }\end{array}$ & $\begin{array}{l}\text { Commitment } \\
\text { and } \\
\text { identification } \\
\text { with the target } \\
\text { of interest }\end{array}$ & $\begin{array}{l}\text { Until the } \\
\text { interest } \\
\text { disappears }\end{array}$ \\
\hline $\begin{array}{l}\text { Formal } \\
\text { working } \\
\text { group }\end{array}$ & $\begin{array}{l}\text { Providing a } \\
\text { product or } \\
\text { service }\end{array}$ & $\begin{array}{l}\text { Formal } \\
\text { membership }\end{array}$ & $\begin{array}{l}\text { Workplace } \\
\text { requirements } \\
\text { and shared } \\
\text { goals }\end{array}$ & $\begin{array}{l}\text { Until the next } \\
\text { reorganisation }\end{array}$ \\
\hline $\begin{array}{l}\text { Project team } \\
\text { or target } \\
\text { community }\end{array}$ & $\begin{array}{l}\text { Carrying out } \\
\text { specific tasks }\end{array}$ & $\begin{array}{l}\text { Formal } \\
\text { assignment (by } \\
\text { a senior } \\
\text { manager) }\end{array}$ & $\begin{array}{l}\text { Milestones and } \\
\text { goals of the } \\
\text { project }\end{array}$ & $\begin{array}{l}\text { Until the } \\
\text { project is } \\
\text { finished }\end{array}$ \\
\hline $\begin{array}{l}\text { Formal } \\
\text { network }\end{array}$ & $\begin{array}{l}\text { Carrying out } \\
\text { specific tasks } \\
\text { within a given } \\
\text { domain of } \\
\text { knowledge }\end{array}$ & $\begin{array}{l}\text { Formal } \\
\text { assignment (by } \\
\text { a senior } \\
\text { manager) }\end{array}$ & $\begin{array}{l}\text { Workplace } \\
\text { requirements } \\
\text { and shared } \\
\text { goals }\end{array}$ & $\begin{array}{l}\text { Until the next } \\
\text { reorganisation } \\
\text { or until the } \\
\text { task is finished }\end{array}$ \\
\hline $\begin{array}{l}\text { Informal } \\
\text { network }\end{array}$ & $\begin{array}{l}\text { Exchange of } \\
\text { knowledge in a } \\
\text { given domain }\end{array}$ & $\begin{array}{l}\text { Voluntary } \\
\text { involvement } \\
\text { (colleagues, } \\
\text { friends, } \\
\text { acquaintances, } \\
\text { etc.) }\end{array}$ & $\begin{array}{l}\text { Mutual needs } \\
\text { and individual } \\
\text { interest }\end{array}$ & $\begin{array}{l}\text { Until the } \\
\text { members lose } \\
\text { interest in } \\
\text { being } \\
\text { connected }\end{array}$ \\
\hline
\end{tabular}

Table 1. Kinds of structures similar to CoPs (based on Al-Hawamdeh, 2003; Collison \& Parcell, 2003; Hislop, 2005; Müller-Prothmann, 2006 and Wenger \& Snyder, 2000)

One of the core aspects of the concept of CoP as set forth by Lave and Wenger (1991) is the role played by "legitimate peripheral participation", which describes how knowledge and competences are transferred in groups through different kinds of guidance, implicit learning and active participation in communities. The members of the community fradually shift from "peripheral participation" to "full participation".

The second fundamental concept in the theories of Lave \& Wenger (1991) is that of "situational learning", which states that learning should take place in the same context in which it will be applied. This "situational learning" is characterised by two basic principles (Smith, 2009):

- It makes no sense to talk about decontextualised, abstract or general knowledge.

- The new knowledge and learning are only conceived properly when they are located inside communities of practice. 
The smooth running of CoPs depends on the existence of the following facilitators (Cummings \& van Zee, 2005; Gannon-Leary \& Fontainha, 2007; Kimble y Hildreth, 2005; Milton, 2005): institutional changes that facilitate their development; the quest for effective models for their operation; progress in the technical innovations needed and the provision of tools that foster modern, flexible environments; open participation and horizontal operating structures; collaborative group work; the right coordinator; participation by recognised experts; a launch meeting; the right degree of autonomy given their functions and characteristics; structures for the communication, interaction and storage of shared knowledge; regular, frequent interaction; task-orientation and deadlines; shared interests, desires and motivations; sound use of technology; and finally, alignment with the organisational strategy.

If these conditions are in place, the benefits can be manifold because: by using dialogue as the cornerstone of the process, there is better interaction and participation; shared responsibility encourages all the members of the community to participate in the learning process; knowledge is viewed as dynamic and the process of building knowledge as an active, collaborative process; and the active stimulus to share knowledge contributes to the development, capture and transfer of good practices.

Ever since they first appeared, CoPs were quickly integrated into organisational management and design, since they offer a new approach for dealing with knowledge in organisations which is focused on people and social structures, and this in turn allows the members of the organisation to learn from each other. Wenger (2007) mentions some of the characteristics that explain organisations' interest in CoPs as a means of developing strategic capacities:

- They enable practitioners to shoulder collective responsibility for managing the knowledge they need, thus recognising that if they have the right structure, they are better poised to do so.

- $\quad$ They create the perfect link between learning and performance since the people who belong to CoPs are also members of other organisational units.

- The participants can address both the dynamic and tacit aspects of sharing and creating as well as the most explicit aspects.

- CoPs are not limited by formal structures; the connections among their members extend beyond geographic and organisational limits.

The kind of relationships that are established between CoPs and the organisation are quite varied and can range from a total lack of recognition of the CoP by the organisation to total institutionalisation (Despres \& Chauvel, 2000). In any case, the integration of CoPs into organisations implies consideration of the four challenges to cultivating CoPs proposed by McDermott (2001):

- Management: This must focus on important aspects for the organisation and its members by finding a member respected by the organisation to coordinate the community, ensuring that people have the time and willingness to participate and basing the community on the organisation's core values.

- Community: Getting the key leaders involved, developing personal relationships among the members and developing a passionate / heavily involved core group, and creating forums for thinking together and systems for sharing information.

- Technology: Facilitating access to technology and contributions to the community.

- Personal: Generating a real dialogue on important, timely issues.

The importance of CoPs for KCM processes within organisations is based on their ability to totally integrate the knowledge and lessons into their social practices without treating them as isolated processes with no connection to day-to-day operations (Lave \& Wenger, 1991). 
The usefulness of CoPs in KCM processes, either online or offline (Table 2), depends not only on the knowledge they can share but also on other basic factors such as a shared identity and values. If these elements are present, the knowledge processes are facilitated and communication of the tacit knowledge becomes simplified, since their existence prompts the social conditions and trust needed to create and manage knowledge (Hislop, 2005).

\begin{tabular}{|c|c|c|}
\hline & Online communities & Offline communities \\
\hline $\begin{array}{l}\text { Ease of } \\
\text { participation }\end{array}$ & $\begin{array}{l}\text { Depends on the group } \\
\text { dynamics, but it is relatively } \\
\text { easy (users should only type } \\
\text { in their comments). }\end{array}$ & $\begin{array}{l}\text { Depends on the design of the } \\
\text { community, the group dynamics } \\
\text { and the degree of comfort at } \\
\text { speaking in public. }\end{array}$ \\
\hline $\begin{array}{l}\text { Usefulness for } \\
\text { geographically } \\
\text { disperse } \\
\text { organisations }\end{array}$ & $\begin{array}{l}\text { Extremely useful. In fact, this } \\
\text { is often the only solution for } \\
\text { effective, affordable } \\
\text { networking. }\end{array}$ & $\begin{array}{l}\text { Complicated and expensive. } \\
\text { However, occasional gatherings } \\
\text { (e.g., yearly) can be highly } \\
\text { productive and generate synergies } \\
\text { and trust. }\end{array}$ \\
\hline $\begin{array}{l}\text { Reusability of the } \\
\text { discussions and } \\
\text { archives }\end{array}$ & Very high. & $\begin{array}{l}\text { Low; special steps are need for } \\
\text { documentation and archives (such } \\
\text { as transcriptions of recordings). }\end{array}$ \\
\hline $\begin{array}{l}\text { Generation of } \\
\text { trust and ties }\end{array}$ & Complicated. & Easy. \\
\hline $\begin{array}{l}\text { Tools to analyse } \\
\text { knowledge- } \\
\text { related } \\
\text { behaviours }\end{array}$ & $\begin{array}{l}\text { Data mining, creation of } \\
\text { clusters, analyses of social } \\
\text { networks (interviews }+ \\
\text { digital real time analyses). }\end{array}$ & $\begin{array}{l}\text { Analyses of social networks } \\
\text { (interviews). }\end{array}$ \\
\hline
\end{tabular}

Table 2. Online vs. offline communities of practice (Rao, 2005, p. 42)

\section{Agents and processes in knowledge creation and management}

The development of KCM strategies implies theoretical and practical mastery of processes of mediating, creating and disseminating individual and collective knowledge and the participation of different agents with a clear delimitation of responsibilities which ensures the proper functioning of these processes and thus the success of the KCM strategy.

\subsection{Processes for knowledge creation and management}

The delimitation and understanding of the processes involved in KCM within organisations necessitates a previous outline of the purpose of this knowledge creation and management. Based on epistemological and ontological dimensions and on the interaction between tacit and explicit knowledge, Nonaka \& Takeuchi (1999) have outlined four processes, now classics in the field (see Figure 1):

- Socialisation: A process in which knowledge is created by sharing one's experience and culture with other people (organisational culture). 
- Externalisation: This entails the formalisation and structuring of tacit knowledge into explicit knowledge through dialogue, schemas, formulas, metaphors, analogies, models, etc. This is perhaps the most important form of knowledge conversion, since it enables explicit new concepts to be created based on tacit knowledge (production - innovation).

- Combination: This is a process of systematisation (analysis, comparison, categorisation, etc.) of the explicit knowledge existing to create new explicit knowledge (information processing).

- Internalisation: Through this process, individuals absorb the explicit knowledge, include it in their cognitive structures and transform it into tacit knowledge (organisational learning).

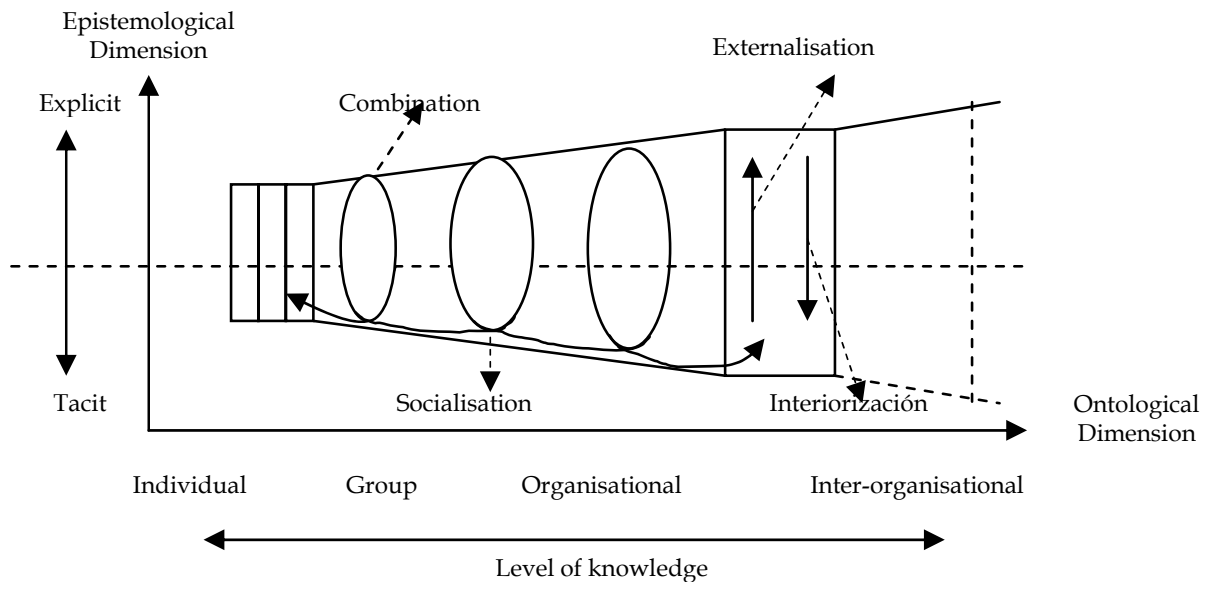

Fig. 1. Spiral of the creation of organisational knowledge (Nonaka \& Takeuchi, 1999, p. 81)

Compared to what we could call the "first generation of knowledge management" spearheaded by Nonaka \& Takeuchi's "knowledge specialist" (1999), which assumes that valuable knowledge already exists within the organisation, through the Knowledge Management Consortium International (www.kmci.org) Firestone \& McElroy (2003) are advocating the second generation of $\mathrm{KCM}$, which is much more inclusive in terms of people, processes and social initiatives. It believes that knowledge does not exist a priori; rather it is something we produce as part of social systems and that we make through individual and shared processes.

As we can see, the main processes involved in KCM can be grouped as follows (RodríguezGómez, 2009):

1. Initial: Concentrating, storing, controlling, capturing, getting, accessing, planning, coordinating, formulating, identifying and locating.

2. Processual: Understanding, valuing, measuring, evaluating, developing, creating and transforming.

3. Final: Applying, exploiting, using, renewing, transforming, sharing and distributing. In addition to the basic and typical processes of $\mathrm{KCM}$, developing an intervention of this kind in any organisation must necessarily take into account the generic aspects of project management, such as the project's appropriateness and pertinence to the characteristics, 
demands and needs of the organisation and its environment; the involvement of personnel in the design and development of the process; and the communication to and awarenessraising of the members of the organisation, including many other factors.

\subsection{The roles and functions of the agents involved}

People are at the heart of KCM processes (Collison \& Parcell, 2003; Firestone, 2008; Gorelick, Milton \& April, 2004; Milton, 2005; Petrides \& Nguyen, 2006; Wiig, 2004), just as they are in any intervention that takes place within the organisational setting.

Usually all the functions related to information, contents, documentation, publications databases and organisational relations, among others, are associated with KCM. The functions, jobs and responsibilities that are usually associated with the people linked to KCM are as follows (Dalkir, 2005):

- Designing information systems (design, evaluation and selection of contents, indexing and representation of knowledge, structure of databases, etc.).

- Managing information systems (maintenance of integrity, quality and value of the data, updating and improvements of the system, etc.).

- Managing information resources to support organisational actions.

- Training.

- $\quad$ Acting as information agencies (information management consultants).

- Providing intelligence on the competition.

- Maintaining client relations with information systems and technologies.

- Designing and producing information services and products.

- Acting as knowledge journalists.

- $\quad$ Acting as KCM policy analysts.

In any event, there is little consensus on who should be in charge of KCM in an organisation or the profile these individuals should have (Al-Hawamdeh, 2003). Rodríguez-Gómez (2009) identify several key personnel categories more or less intensely involved in KCM processes (Dalkir, 2005; Davenport \& Prusak, 2001; Frappaolo, 2006; Gorelick, Milton \& April, 2004; Liebowitz, 1999; Milton, 2005):

- Knowledge-oriented personnel: This includes all individuals who are part of the organisation and create, share, investigate and use knowledge fundamental in the functioning of the organisation in their day-to-day jobs.

- Knowledge management workers - experts - or knowledge engineers: This includes the members of the organisation who are capable of identifying and extracting knowledge from the people who possess it and of organising, storing and updating it.

- Administrators of knowledge projects: This includes people who are in charge of specific projects and must therefore have knowledge of the sphere of the project and understand how the people working on it are, think and act. They perform jobs like: "developing the project objectives, setting up and administering work teams, determining and administering the client expectations, supervising budgets and project programmes, and identifying and resolving problems in the projects" (Davenport \& Prusak, 2001, p. 129)

- Knowledge analyst: This is the person in charge of gathering, organising and disseminating the knowledge, usually on demand. He or she is in charge of analysing and storing good practices.

- Knowledge manager: This is usually a coordinator of the knowledge processes and is thus appropriate in organisations with the need for several groups of people to participate in the knowledge management processes. 
- Chief Knowledge Officer (CKO): This is a well-known figure in KCM, similar to the "learning director", "director of intellectual capital", "director of human resources" and similar positions. Thurow (2004) asserts that in light of the characteristics of our society, all organisations should have a $\mathrm{CKO}$ on their managerial teams. Some of the responsibilities and/or functions of the CKO include (Dalkir, 2005; Davenport \& Prusak, 2001): defending knowledge and its learning; formulating the knowledge management strategy; designing, implementing and supervising the knowledge infrastructure; administering relations with outside suppliers of information and knowledge; providing critical information in the process of creating and using knowledge in the entire company; designing and implementing a company's knowledge codification methods; measuring and administering the value of knowledge; managing the knowledge management operations; managing the knowledge management professionals in the organisation; spearheading the development of a knowledge strategy; positively influencing organisational change; developing a knowledge culture; maximising the return on KCM investment; improving the innovation and commercialisation of ideas; and preventing the loss of knowledge.

- Chief Learning Officer (CLO): The CLO is in charge of spearheading the professional development in the organisation, focusing on the organisational culture, the kind of knowledge and lessons and the technology used. Ultimately, this person must foster organisational learning.

Some of these categories of KCM professionals are part of what De Tena (2004) calls the "core team" (see Table 3).

"While the knowledge worker is any member of the organisation involved in a knowledgeintensive job, the knowledge professional is one who serves as a bridge between the knowledge workers and the decision-makers. These people have the competences needed to deal with the organisational knowledge and promote KM within the organisation" (AlHawamdeh, 2003, p. 181).

According to the majority of authors (CEN, 2004; Dalkir, 2005; Gallego \& Ongallo, 2004; Gorelick, Milton \& April, 2004; Milton, 2005), the basic KCM team would include four people who would focus on KCM more or less exclusively and intensely according to the resources available.

$\begin{array}{ll}\begin{array}{l}\text { Technical } \\ \text { Coordinator }\end{array} & \begin{array}{l}\text { He or she suggests the conceptual approach to the system by } \\ \text { analysing the processes, the context and individuals' capacities. This } \\ \text { position is the most similar to a CKO. }\end{array} \\ \begin{array}{l}\text { This person remains close to the workers, getting the most from each } \\ \text { of them. }\end{array} \\ \begin{array}{l}\text { Technology } \\ \text { Coordinator }\end{array} \\ \begin{array}{l}\text { This person's place is near the technology, creating the "motorways of } \\ \text { interaction". }\end{array} \\ \begin{array}{l}\text { Network } \\ \text { Knowledge }\end{array}\end{array}$

Table 3. Functions of the "core team" (De Tena, 2004, p. 169) 


\section{Method}

During the second stage in the ACCELERA project, which was carried out between 2006 and 2009, the activities centred on analysing the roles of the agents and processes that are involved and take part in KCM in virtual environments. The objective was twofold:

- To describe and analyse the characteristics of the different agents that take part in KCM networks (participants, moderators and knowledge managers) as well as the strategies they use during the processes they carry out.

- To analyse some of the fundamental processes and factors in the proper development of online KCM, including participation, motivation, group dynamics (cohesion, productivity, etc.), ethics, communication processes and content analysis.

The final sample in the study was made up of 343 people (14 CoP moderators, 28 institutional managers and $301 \mathrm{CoP}$ participants) in fourteen CoPs chosen intentionally according to three criteria: a) they develop KCM processes in socio-educational/training environments; b) their KCM is based on online and/or in-person communities of practice; and c) the participants had easy access to the CoP.

The CoPs ultimately chosen came from the Centre for Legal Studies and Specialised Training of the Generalitat de Catalunya (4 CoPs), the Health Protection Agency of the Generalitat de Catalunya (4 CoPs), the Educational Management Support Network in Latin America (2 CoPs), the Coyahique Commune in Chile (2 CoPs) and the Autonomous University of Barcelona (2 CoPs).

The methods used to gather information included an exploratory interview with the institutional managers, knowledge managers and moderators of the fourteen communities, content analysis of the forums based on the Community of Inquiry model (Garrison, Anderson \& Archer, 2001), analysis of the general operation of the communities, and questionnaires for the participants and two discussion groups with the participation of some members of the communities, institutional managers and experts in various fields of KCM.

All the instruments were devised based on the following measures, which were in turn drawn from the basic dimensions of any KCM process (Collison \& Parcell, 2003; Gorelick, Milton a\& April, 2004; Milton, 2005; Petrides \& Nguyen, 2006, Rodríguez-Gomez, 2009):

1. Information and communication technologies for KCM: Today it is difficult to imagine a KCM system that does not entail the use of ICTs, especially in the processes of transferring, storing, processing, accessing and organising data, information and knowledge. However, a disproportionate use of ICTs can pervert KCM systems and make them resemble data and information management systems.

2. KCM processes: It is crucial to plan all the KCM-related processes. The novelty and complexity of $\mathrm{KCM}$ processes means that organisations focus on and invest many resources into planning pilot tests and later forget to disseminate this project to the rest of the organisation. For example, the absence or lack of clarity in the KCM goals can serve as an impediment to the success of a project, as can the clarity of the language and goals or fitting the breadth of interpretations attributable to the concepts used in this field (such as knowledge, information, learning, etc.). Likewise, it is important to stress that KCM initiatives can end up in failure without a prior diagnostic evaluation that helps us to contextualise their development and indicates how and why to proceed, if the personal responsibilities are not clarified and established or if the existence of a $\mathrm{KCM}$ team devoted especially to designing, developing and evaluating the process is not promoted. 
3. People in KCM, particularly their competences, motivations, attitudes, beliefs and values: If knowledge is personal and sticky, it is crucial to motivate and encourage the members of the organisation to share, use and create it on a regular basis. KCM is impossible if people do not value the importance of knowledge, are unwilling to share and create knowledge or do not have the competences needed to so do.

\section{Results}

The analysis and validation of the data obtained from the participants and institutional managers of the fourteen CoPs analysed, as well as the contributions from the numerous experts invited to participate in the discussion groups on the study, enable us to present a proposal for KCM processes and agents based on CoPs and on the ACCELERA model for KCM.

The smooth functioning of online KCM requires the involvement of at least five agents with specified functions, profiles, spaces for participation and roles. What is more, we should consider the fact that online KCM entails different stages of planning, development and dissemination, and in this sense, the participation of any given agent can be related to each of the processes involved (see Figure 2).

In the case of the ACCELERA KCM model, the agents involved in the design and development of any process are the following (Rodríguez-Gómez, Armengol, Fuentes \& Muñoz, 2011, p.169-170):

- Institutional Manager (IM). This is the person who takes the decision to offer, provide, suggest and even impose a way of working focused on KCM. They prescribe what the goals and objectives to be achieved are, and they assign the Network Director to design and supervise the KCM network in the institution that they run.

- Network Director (D). They suggest to institutions that they participate in the online KCM for organisational and institutional improvement. They must provide answers to these organisations' specific requests based on initial diagnostics that end up in specific proposals for personalised, well-coordinated interventions based on the leadership position they hold. This person is in charge of planning and supervising the development of the intervention and the functioning of the network. Sometimes they may also hold the intellectual rights to the platform which is used to support the development of the network.

- ICT Facilitator (IT). This person takes all the steps needed to ensure that the support tool used is ready to go for the participants. They take part in the design of simple interaction tools that are user-friendly, functional and practical, according to the standards of usability, accessibility and security, always focusing on the user. Once the design has been made, they must ensure its execution and the administration of the network by ensuring its functioning, supporting the participants, following up and providing technical maintenance of the network, working in close cooperation with the network moderators and creating, if needed, technical guides, while also participating in establishing quality criteria (relevance, focus, precision, exhaustiveness, reliability, punctuality, detail, format and comprehensibility) for more effective, efficient communication.

- Network Moderator (NM). This person starts forums of debate or other activities which can be conducted online, guides the process, intervenes if the debate becomes complicated or does not happen, orders the information and synthesises the knowledge that is generated and proposes outside content to feed the debate if needed. They also play a key role in motivating the participants and promoting the socialisation and 
generation of a culture that fosters autonomy and self-regulation in order to improve the quality and continuity of the KCM.

- Participants (P). The participants are the users of the network, and they are truly at its core since the network has no raison d'etre without them. They must shoulder the responsibility of joining the network and participating in it periodically. There are numerous kinds of users, although practice distinguishes three roles: the core active group, the peripheral group with more sporadic participation and the lurkers or passive participants.

The participants must converse with each other and establish an enriching dialogue that promotes the exchange of information based on criteria established by the director and moderator of the network. Their participation should produce new and relevant information for the joint construction of knowledge. The interaction they engage in should be sustained on the outline of ideas, the formulation of questions, discussions on different alternative approaches, contributions of relevant materials and documentation, reflections on the topics proposed and their practice, the sharing of their own or familiar experiences, briefings and criticisms of works, doubts, successes, difficulties and more.

$\mathrm{KCM}$ professionals require a multidisciplinary set of competences which enable them to successful deal with any of the processes inherent in KCM (Rodríguez-Gómez, 2009), such as searching for information, using knowledge, evaluating information and knowledge, reformulating questions, filtering information and knowledge, generating contents, synthesising, and organising and classifying data and information. Al-Hawamdeh (2003) groups the set of competences that KCM professionals should have into six categories: technology, information, communication, leadership and management, analysis and personal qualities.

As well as these considerations, it should be borne in mind that in addition to the objective of the network and the desirable active participation of its users, the size of the groups, the number of participants, the forms of participation and the distribution of roles and responsibilities of all the agents affect the KCM. In particular, the entire set of aptitudes and attitudes of each agent involved; the planning, categorisation and distribution of jobs; control over the interactions as the foundation of the communication systems; ethics and the governance of the network or the type of structures that govern the organisation; and the management of the content flow are just a few of the issues which should be taken into consideration.

An integration of phases, agents and processes validated in ACCELERA is shown in Table 4. The PRIOR phase includes the presentation of the KCM through an organisational and cultural diagnostic, which enables the needs to be detected and prioritised. Thus, the map of existing knowledge in the organisation can be completed with the contributions by the participants in the development phase.

After the organisational structure has been evaluated and the strengths and weaknesses identified comes the PLANNING stage. The first step is to assemble a team that will design and develop the KCM process. The members of this team must complement each other and have diverse knowledge (intellectual capital, technology systems, organisational learning, training, management of cultural change, group dynamics, etc.). The members of the group must obviously include the Institutional Manager and the Network Director. At the same time, direct contacts should be forged with the Network Moderator and the ICT Facilitator. The processes in the IMPLEMENTATION phase refer to the nature of the communication (characteristics, contents, processes, etc.), the participatory processes (natural or induced), the cohesion among the members of the network and their motivation. The start of this 
phase enables the participants to access the network so that they can shift from tacit (personal) knowledge to explicit (shared) knowledge. This is when a socialisation process gets underway in which the participants share their individual knowledge (theoretical and practical, aptitudes, attitudes, etc.), with the goal of contributing to the KCM.

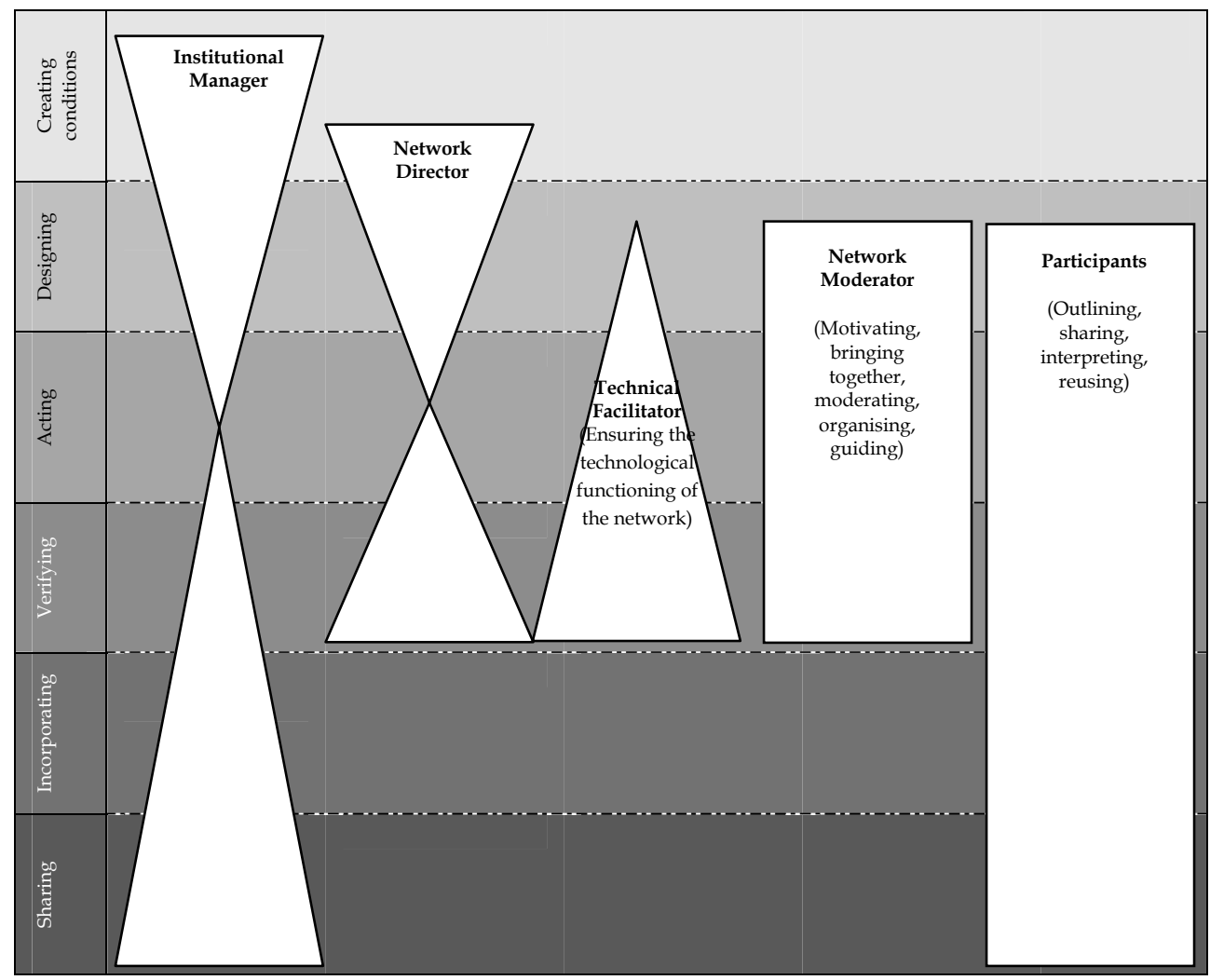

Fig. 2. Roles and processes in $\mathrm{KCM}$

The Network Moderator appointed must guide and stimulate the debate, help with group cohesion through regular monitoring of the network, and organise the information and knowledge that are generated through precise moderation. The participants' interventions entail sharing their experience and culture, making their personal knowledge explicit, interpreting and reusing their colleagues' contributions, reflecting on their own beliefs and culture, socially elaborating information and formalising shared knowledge, among others.

One important way to improve the efficacy of a KCM network is to encourage the participants to start a dialogue that grows as they share schema, formulas, metaphors, analogies, documents, bibliographic references, thoughts, feelings, beliefs, models, etc. and to encourage the contributions to be analysed, compared, categorised, interpreted, processes, criticised, reused, systematised, etc.

This dialogue takes on meaning by combining externalisation and individual explanation with the reflection on a social network, giving rise to the creation and internalisation of new 
knowledge, knowledge that can be organisational and which, if it is, should directly contribute to institutional improvement.

\begin{tabular}{|c|c|c|c|}
\hline PHASES & ACTIONS & DESCRIPTION & $\begin{array}{l}\text { AGENT } \\
\text { RESPONSIBLE }\end{array}$ \\
\hline \multirow{4}{*}{ 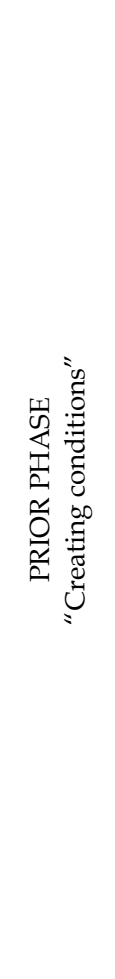 } & $\begin{array}{l}\text { KNOWLEDGE OF } \\
\text { THE CONTEXT } \\
\text { OF ACTION }\end{array}$ & $\begin{array}{l}\text { Determining the origin of the demand. } \\
\text { Identifying the ultimate purpose of creating the } \\
\text { KM network: to change values, to improve the } \\
\text { curriculum, for professional development, for } \\
\text { organisational reasons... } \\
\text { Contextual conditions: a) analysis of external } \\
\text { factors: administrative, academic and economic } \\
\text { autonomy, and b) analysis of internal factors: } \\
\text { culture and climate of the institution, } \\
\text { educational purposes, structures, interactive } \\
\text { system, role of the managerial team, tradition } \\
\text { of teamwork, tradition of reflexive processes of } \\
\text { analysis and problem-solving. }\end{array}$ & $\begin{array}{l}\text { Institutional } \\
\text { Manager }\end{array}$ \\
\hline & $\begin{array}{l}\text { DETECTION OF } \\
\text { NEEDS }\end{array}$ & Categorisation and prioritisation. & \multirow{3}{*}{$\begin{array}{l}\text { Institutional } \\
\text { Manager } \\
\text { Network Director }\end{array}$} \\
\hline & $\begin{array}{l}\text { DETECTION OF } \\
\text { OBSTACLES TO } \\
\text { LAUNCHING } \\
\text { THE NETWORK }\end{array}$ & $\begin{array}{l}\text { Degree of motivation. } \\
\text { Degree of integration in relations. } \\
\text { Group working dynamic. } \\
\text { Capacity to adjust to new situations. } \\
\text { Level of harmony to create shared visions. } \\
\text { Existence of leaders with the ability to } \\
\text { motivate. } \\
\text { Involvement and support of initiatives. }\end{array}$ & \\
\hline & $\begin{array}{l}\text { IDENTIFICATION } \\
\text { OF ISSUES THAT } \\
\text { MIGHT BE } \\
\text { ADDRESSED }\end{array}$ & $\begin{array}{l}\text { Degree of efficiency of processes. } \\
\text { New challenges and demands. } \\
\text { Nature of the contents to be improved: } \\
\text { structural, academic, management, etc. }\end{array}$ & \\
\hline \multirow[b]{2}{*}{ 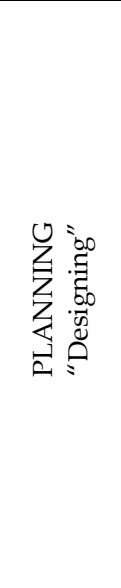 } & $\begin{array}{l}\text { SETTING THE } \\
\text { OBJECTIVES OF } \\
\text { THE NETWORK }\end{array}$ & $\begin{array}{l}\text { Clarification and precise formulation of the } \\
\text { problems and dysfunctions which can be } \\
\text { improved or issues to be addressed. }\end{array}$ & $\begin{array}{l}\text { Institutional } \\
\text { Manager } \\
\text { Participants }\end{array}$ \\
\hline & $\begin{array}{l}\text { GENERAL AND } \\
\text { SPECIFIC } \\
\text { ACTION PLANS }\end{array}$ & $\begin{array}{l}\text { Organisation of general avenues of action, } \\
\text { definition of the working methodology and } \\
\text { outline of the action plan: step-by-step actions } \\
\text { (specific, identifiable, observable, matching the } \\
\text { objectives), logistical planning to carry them } \\
\text { out, definition of a timeline. } \\
\text { Defining the roles and functions of the people } \\
\text { involved and agreeing on the process and } \\
\text { mechanisms of participation and control. } \\
\text { Mobilisation of the resources needed. } \\
\text { Assessment of the costs, risks and } \\
\text { opportunities of embarking upon a KCM }\end{array}$ & $\begin{array}{l}\text { Institutional } \\
\text { Manager } \\
\text { Network Director } \\
\text { ICT Facilitator } \\
\text { Participants } \\
\text { Moderator }\end{array}$ \\
\hline
\end{tabular}




\begin{tabular}{|c|c|c|c|}
\hline & & $\begin{array}{l}\text { process. } \\
\text { Deciding on the most appropriate kinds of } \\
\text { strategies and instruments to inform the } \\
\text { stakeholders. } \\
\text { Defining the training needs to participate in a } \\
\text { virtual KCM network. } \\
\text { Defining the mechanisms to motivate the } \\
\text { participants. }\end{array}$ & \\
\hline & $\begin{array}{l}\text { PLAN FOR THE } \\
\text { EVALUATION } \\
\text { PROCESS }\end{array}$ & $\begin{array}{l}\text { Defining evaluation criteria and designing the } \\
\text { revision process and instruments: data } \\
\text { gathering, drawing up reports, timeline... } \\
\text { Design of feedback mechanisms. } \\
\text { Dissemination of the results of the evaluation } \\
\text { regarding the process and the agreements } \\
\text { reached. } \\
\text { Timeline of the evaluation plan. }\end{array}$ & $\begin{array}{l}\text { Institutional } \\
\text { Manager } \\
\text { Network Director }\end{array}$ \\
\hline \multirow[t]{3}{*}{ 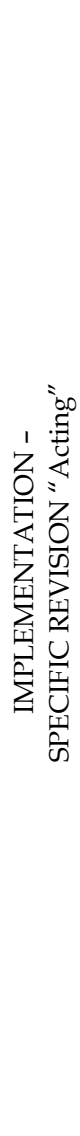 } & $\begin{array}{l}\text { DEVELOPMENT } \\
\text { OF ACTION } \\
\text { PLAN }\end{array}$ & $\begin{array}{l}\text { Presenting the guide to using the platform. } \\
\text { Fostering access to the network and resolving } \\
\text { technical problems, if there are any. } \\
\text { Guiding the project towards the objectives } \\
\text { established. } \\
\text { Motivating and creating a pleasant climate. } \\
\text { Establishing moderation criteria and ensuring } \\
\text { that they are followed. } \\
\text { Organising and suggesting work. } \\
\text { Offering feedback and redirecting the topics, if } \\
\text { necessary. } \\
\text { Reinforcing relationships among people; } \\
\text { organising and coordination interaction among } \\
\text { the participants. } \\
\text { Facilitating the KCM: Discovering the hot } \\
\text { points in discussions, guaranteeing the } \\
\text { relevancy and quality of the contributions, } \\
\text { introducing external information when } \\
\text { necessary. } \\
\text { Ascertaining the problems as they arise in } \\
\text { order to affect them. } \\
\text { Proposing syntheses and/or conclusions. }\end{array}$ & $\begin{array}{l}\text { ICT Facilitator } \\
\text { Moderator }\end{array}$ \\
\hline & $\begin{array}{l}\text { PARTICIPATION } \\
\text { IN THE } \\
\text { NETWORK } \\
\text { DESIGNED }\end{array}$ & $\begin{array}{l}\text { Active and constructive participation in the } \\
\text { KCM network launched. }\end{array}$ & Participants \\
\hline & $\begin{array}{l}\text { DEVELOPMENT } \\
\text { OF FOLLOW-UP } \\
\text { AND REVISION } \\
\text { MECHANISMS }\end{array}$ & $\begin{array}{l}\text { Writing efficacy reports or suggestions during } \\
\text { the course of the network, detecting difficulties } \\
\text { and progress, launching self-observation and } \\
\text { revision mechanisms, launching feedback } \\
\text { mechanisms. }\end{array}$ & $\begin{array}{l}\text { ICT Facilitator } \\
\text { Moderator }\end{array}$ \\
\hline
\end{tabular}




\begin{tabular}{|c|c|c|c|}
\hline \multirow{3}{*}{ 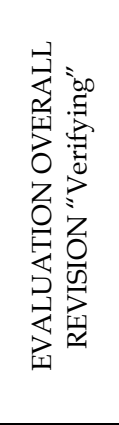 } & $\begin{array}{l}\text { DETECTION OF } \\
\text { DYSFUNCTIONS }\end{array}$ & $\begin{array}{l}\text { The interaction or inter-dependence of the } \\
\text { factors that trigger the dysfunctions noticed. }\end{array}$ & $\begin{array}{l}\text { All the } \\
\text { stakeholders }\end{array}$ \\
\hline & $\begin{array}{l}\text { SEARCH FOR } \\
\text { ALTERNATIVES }\end{array}$ & $\begin{array}{l}\text { Searching for solutions to the problems that } \\
\text { arise. } \\
\text { Introducing modifications to the initial plan to } \\
\text { rectify the dysfunctions noticed. }\end{array}$ & $\begin{array}{l}\text { All the } \\
\text { stakeholders }\end{array}$ \\
\hline & $\begin{array}{l}\text { OVERALL } \\
\text { ASSESSMENT } \\
\text { REPORT }\end{array}$ & $\begin{array}{l}\text { Drawing up an overall evaluative report based } \\
\text { on the observation and monitoring plan and on } \\
\text { the reports from the revision process. } \\
\text { Criticism and reflection on the process and } \\
\text { practice. }\end{array}$ & $\begin{array}{l}\text { Network Director, } \\
\text { ICT Facilitator } \\
\text { and Moderator }\end{array}$ \\
\hline \multirow{3}{*}{ 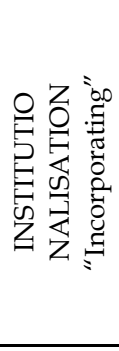 } & $\begin{array}{l}\text { MAKING THE } \\
\text { MECHANISMS } \\
\text { ESTABLISHED } \\
\text { ROUTINE }\end{array}$ & $\begin{array}{l}\text { Including KCM into the organisational } \\
\text { structure. }\end{array}$ & \multirow{4}{*}{$\begin{array}{l}\text { Institutional } \\
\text { Manager } \\
\text { Participants }\end{array}$} \\
\hline & \begin{tabular}{|l} 
ADDRESSING \\
NEW ISSUES \\
\end{tabular} & $\begin{array}{l}\text { Creating dynamics that encourage the } \\
\text { adoption of new KCM networks. }\end{array}$ & \\
\hline & $\begin{array}{l}\text { SURVIVAL OVER } \\
\text { TIME }\end{array}$ & $\begin{array}{l}\text { Establishing support mechanisms. } \\
\text { Improvements above and beyond the people } \\
\text { who launched it. }\end{array}$ & \\
\hline 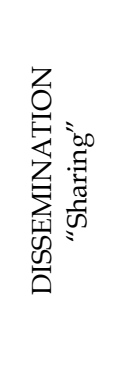 & $\begin{array}{l}\text { EXTERNALISATI } \\
\text { ON }\end{array}$ & $\begin{array}{l}\text { Drawing up strategies to disseminate the } \\
\text { experience. } \\
\text { Motivating the participants to share the } \\
\text { experience. }\end{array}$ & \\
\hline
\end{tabular}

Table 4. Phases and actions in the ACCELERA network (based on Gairín, 2002)

The end of cycles must signal EVALUATION processes. Drawing up evaluation reports from the vantage point of each of the stakeholders involved should allow the planning (objectives, tasks proposed, timing, etc.), construction and selection of instruments and technological resources, information outlining and gathering and the agility and effectiveness of the knowledge generated to be assessed.

Likewise, it is important to evaluate to what extent the benefits of online KCM may last over time and become a valuable asset, that is, to assess the impact of the network on the institution.

Finally, the experience must be INSTITUTIONALISED. Communication of the experience online can give rise to organisational knowledge which must be internally disseminated in order to promote institutional improvement and lead, if possible, to generating interorganisational knowledge. The external DISSEMINATION is extremely important for organising the knowledge generated and exploiting it in a way that enables the participating organisations to keep and/or generate a competitive advantage. 


\section{Conclusions}

The concern with innovation and improvement in educational centres has always been present in the individuals involved in their management and operation, although the focal points have changed according to the successes achieved and expected. The initial importance of extraordinary teaching staff is no longer as important compared as have the necessary collective, coordinated efforts when the period of schooling is on the rise. Here we are discussing schools as spaces of innovation, and the stress is on collaborative work.

Making the concern with endowing educational institutions with a shared, common culture promotes consensus and the clarification of objectives (reformulating the educational project, the curricular project, the normative regulations, etc.) and the transformation of structures (spaces and times for meetings, development of catalysts, etc.); that is, the goal is to reinforce the organisation as a global reality by developing a support structure and collaborative work.

This structural concern has not been sufficient to achieve the effects sought, and thus in recent years the importance of people and organisational processes has been reconsidered. First, the personal characteristics and contextual conditions related to professional collaboration have been analysed, while secondly there has been an attempt to identify effective processes associated with professional and organisational development.

The concepts of learning community and community of practice developed in this vein include the feeling of belonging, as well as a clearly determined orientation: the interaction among the members of the community should enable each and every member to progress while also strengthening a shared culture and the possibility that learning and organisational improvement can come to fruition. This is the individual and collective learning that justifies calling these communities formative, even if they adopt different guises, such as professional communities of practice.

Professional communities of practice (CoPs) can be set up and developed either in person or through the web. Virtual communities of practice offer several advantages over the more traditional method of working teams: (a) they make it possible to forge asynchronic relationships that facilitate collaborative activities without threatening individual autonomy, thus leading to the acquisition of knowledge constructively and with high social interaction; (b) they facilitate processes of collaboration in which the participants produce knowledge actively by formulating ideas in writing which are shared and constructed based on others' reactions and responses; (c) in the opinion of Silva (2004), they allow more time to consider opinions after reflection and to discuss complex ideas; (d) our knowledge can be extended because of the diversity of the other participants; and (e) they take advantage of the emancipating capacity of certain uses of technology, its capacity to impact users and their environment, improvements in coordinating actions and a reduction in costs (Smith \& Kollock, 2003).

However, we should bear in mind several limitations: (a) a restriction due to the written language, which is linked to finding the right tone, the fluidity of the conversation and the loss of richness from gestural language, especially for those with lower writing skills; (b) excess information: over-saturation of information, high time demands and complications in managing all this information; (c) the lack of training in the use of the platform by both the moderators and the other participants is yet another stumbling block that must be overcome for the online training actions to be effective; and (d) the most appropriate materials and/or knowledge are not always available, leading to technical problem related to the set-up of the system and the access to and use of the network. 
However, the working models used and the tools that accompany them are as important as the people. Their facilitating or limiting role is closely tied to the choices made and implemented. Given the novelty of this field of education, the effective creation and management of the collective knowledge generated by professionals requires specific models, strategies and instruments.

The ACCELERA model, which is specific to KCM in the field of education, has enabled us to analyse, experiment with and validate the working processes among education professionals based on a collective reflection grounded on questions. Likewise, it has also helped to clarify the roles and functions of the stakeholders involved in KCM.

Even though KCM should involve all the members of the organisation, the team in charge of it should plan the process to be used by aligning its objectives with the organisational strategy by defining the resources needed, designing KCM-specific strategies and dynamics, giving instructions for individual and/or group tasks, either guided or independent, choosing models of good practices, proposing case studies and readings, assessing and choosing the technologies needed (groupware, e-learning platforms, databases, blogs, wikis, repositories, messengers, social bookmarkers, etc.) and determining the evaluation system in an integrated, continuous fashion throughout the entire process.

However, improving the efforts of the KCM agents requires them to keep further pursuing several directions. Our studies have experimented with KCM models by delimiting the role of the managers and moderators, using varied motivation and participation strategies and further examining the usefulness of synchronous or asynchronous tools, while always using voluntary professional groups on an occasional basis. The crux of the matter is that if we want to promote significant developments, we have to consider the involvement of the entire organisation or most of it in $\mathrm{KCM}$ processes and thus overcome the dilemma of volunteers "versus" everyone in the organisation.

Likewise, despite the considerable surge in studies on KCM, it is worth continuing to work based on specific approaches in and from the field of education which enable us to evaluate, propose and validate procedures to create and manage knowledge in both in-person and online communities of practice according to the stage of education and the target groups. The goal is to analyse the personal, organisational and social effects entailed by the intensive use of CoPs by an organisation, while also providing instruments for self-evaluation to improve their functioning and tools to identify and validate the informal learning they generate.

However, the effective, widespread development of KCM approaches would not be possible without the implementation and development of strategies to support them. In this respect, headway is needed in identifying strategies for personal knowledge linked to the resistances to collective work and the development of the individuals in the organisation, such as peer guidance, mentoring or coaching.

Therefore, the problem is not so much one of conception as primarily one of development. The goal is to more deeply define the models and strategies that enable professionals to work together collaboratively, and then for their collaboration to generate positive results and effects for both individuals and the organisation.

\section{Acknowledgment}

Contributions from the study "Agentes y procesos en la gestión del conocimiento en red"(Agents and process in networked knowledge management). Ministry of Education and Culture, National R\&D Plan (ref. SEJ2007-67093/EDUC), supervised by Joaquín Gairín. 


\section{References}

Al-Hawamdeh, S. (2003). Knowledge Management. Cultivating knowledge professionals, Chandos, ISBN 978-1843340379, Publishing, Oxford.

Anderson, T. \& Kanuka, H. (1997). On-Line Forums: new platforms for professional development and Group Collaboration. Retrieved from <http://www.ascuscs.org.jcmc/vol3/issue3/anderson.html>

Ardichvili, A., Page, V, \& Wentling, T. (2003). Motivation and barriers to participation in virtual knowledge sharing teams. Journal of Knowledge Management, 7(1), pp. 64-77, ISSN 1367-3270

Armengol, C. \& Rodríguez, D. (2006). La moderación de redes: algunos aspectos a considerar. Educar, 37, pp.85-100, ISSN 0211-819X

Aubusson, P. Steele, F., Dinham, S. \& Brady, L. (2007). Action learning in teacher learning community formation: informative or transformative? Teacher Development, 11, 2, pp. 133-148, ISSN 1366-4530

Ballester, L., Orte, C., Oliver, J.L. \& MARCH, M.X. (2006). Metodología para el trabajo socioeducativo en red. Comunicación presentada en el IV Congreso Estatal del Educador Social, Retrieved from <http://www.eduso.net/archivos/IVcongreso/comunicaciones/c65.pdf>

Bolam, R., McMahon, A. Stoll, L., Thomas, S., Wallace, M., Greenwood, A., Hawkey, K., Ingram, M., Atkinson, A. \& Smith, M. (2005). Creating and Sustaining Effective Professional Learning Communities. University of Bristol, Bristol, Retrieved from <www.dcsf.gov.uk/research/data/uploadfiles/RR637.pdf >

Cabero, J. \& Llorente, M.C. (2007). Propuesta de colaboración en educación a distancia y tecnología para el aprendizaje. Edutec. Revista Electrónica de Tecnología Educativa, 23, ISSN 1135-9250, Retrieved from <http://edutec.rediris.es/Revelec2/revelec23/jcabero/jcabero.html>

CEN (2004). European Guide to good Practice in Knowledge Management - Part 3. SME Implementation. CEN, Brussels, Retrieved from

<http://www.cen.eu/cenorm/sectors/sectors/isss/cen+workshop+agreements/k nowledge+management.asp $>$

Collison, C. \& Parcell, G. (2003). La Gestión del Conocimiento. Lecciones prácticas de una empresa líder. Paidós, ISBN 9788449313677, Barcelona.

Cummings, S. \& van Zee, A. (2005). Communities of practice and Networks: reviewing two perspectives on social learning. Knowledge Management for Development Journal, 1, 1, pp. 8-22, ISSN 1947-4199

Dalkir, K. (2005). Knowledge Management in Theory and Practice. Elsevier, ISBN 9780750678643, Oxford

Davenport, T. \& Prusak, L. (2001). Conocimiento en Acción. Cómo las organizaciones manejan lo que saben. Pearson Education, ISBN 9789879460290, Buenos Aries

De Benito, B. (1999). Taller: Redes y trabajo colaborativo entre profesores. Proceedings of EDUTEC 99. Retrieved from <http://gte.uib.es/articulo/EDUTEC99.pdf>

De Tena Rubio, R. (2004). La implantación de sistemas de gestión del conocimiento. In: Conocimiento y Gestión, D. Gallego \& C. Ongallo (Eds.), (pp. 145-180). Pearson Educación, ISBN 9788420541129, Madrid 
Dering, A., Cunninghan, S. \& Withby, K. (2006). Developing leadership teams within an EAZ network: what makes for success? School leadership and Management, 26, 2, pp.107-123, ISSN 1363-2434

Despres, CH. \& Chauvel, D. (Eds.) (2000). Knowledge Horizons. The present and the promise of Knowledge Management, Butterworth-Heinemann, ISBN 978-0750672474, Boston

Fernández-Enguita, M. (2008). ¿Qué hay de nuevo bajo el sol? De las organizaciones y los grupos a las redes. Cuadernos de Pedagogía, 385, pp.12-19, ISSN 0210-0630

Firestone, J. M. (2008). On Doing Knowledge Management. Knowledge Management Research E Practice, 6, pp. 13-22, ISSN 1477-8238

Firestone, J. M. \& McElroy, M. W. (2003). Key issues in the New Knowledge Management, Elsevier, ISBN 978-0750676557, Burlington

Frappaolo, C. (2006). Knowledge Management. Capstone Publishing, ISBN 978-1841127057, West Susex

Gairín, J. (2006). Las comunidades virtuales de aprendizaje. Educar ,37, pp. 41-64, ISSN 0211-819X

Gairín, J. (2008). Las comunidades formativas de aprendizaje en el contexto institucional. Gestión de centros.com. Wolters Kluver Educación, Madrid

Gairín, J., Rodríguez-Gómez, D. \& Armengol, C. (2010). Who exactly is the moderator? A consideration of online knowledge management network moderation in educational organisations. Computers $\mathcal{E}$ Education, 55, 1, pp. 304-312, ISSN 03601315

Garín, J. (2011) (Ed.). El trabajo colaborativo en red. Actores y procesos en la creación y gestión del conocimiento colectivo, DaVinci, ISBN 9788492651481, Barcelona

Gallego, D. \& Ongallo, C. (Eds). (2004). Conocimiento y gestión. La gestión del conocimiento para la mejora de las personas y las organizaciones, Pearson Prentice Hall, ISBN 9788420541129, Madrid

Gannon-Leary,P. \& Fontainha, E. (2007). Communities of practice and virtual learning communities: benefits, barriers and success factors. E-learning Papers, 5, Retrieved from <http://www.elearningeuropa.info/files/media/media13563.pdf>

Gea, M., Gutierrez, F. L., Garrido, J. L. \& Cañas, J. (2002). AMENITIES: Metodología de Modelado de Sistemas Cooperativos. Proceedings of III Congreso Internacional de Interacción Persona-Ordenador, Madrid. Retrieved from <http:/ / lsi.ugr.es/ mgea/workshops/coline02/Articulos/mgea.pdf>

González, A. P. (2005). La Organización del trabajo y la formación en los nuevos escenarios: el papel de las TIC. Proceedings of Congreso: IV CIFO. IV Congreso de Formación para el trabajo: Nuevos escenarios de trabajo y nuevos retos en la Formación, Retrieved from <http://tecnologiaedu.us.es/formaytrabajo/Documentos/pon3.pdf>

Gorelick, C., Milton, N. \& April, K. (2004). Performance Through Learning. Knowledge Management in Practice. Elsevier, ISBN 978-0750675826, Burlington

Hardon, A. (2005). Virtual knowledge communities: lessons learned in making them work. Knowledge Management for Development Journal, 1, 1, pp. 71-78, ISSN 1947-4199

Hargreaves, A. \& Giles, C. (2003). The Knowledge Society School: An Endangered Entity. In: Teaching in the Knowledge Society: Education in the Age of Insecurity, A. Hargreaves (Ed.), pp. 127-159, Open University Press, ISBN 978-0807743591, Philadelphia

Hislop, D. (2005). Knowledge Management in Organizations. A critical introduction. Oxford University Press, ISBN-13: 978-0199262069, Oxford 
Huang, K-T., Lee, Y.W. \& Wang, R. (1999). Calidad de la información y gestión del conocimiento. Aenor, ISBN 9788481431902, Madrid

Jeon, S., Kim, Y.G. \& Koh, J. (2011). An integrative model for knowledge sharing in communities-of-practice. Journal of Knowledge Management, 15, 2, pp. 251-269, ISSN $1367-3270$

Kimmble, C. \& Hildreth, P. (2005). Dualities, distributed communities of practice and knowledge management. Journal of Knowledge Management, 9, 4, pp. 102-113, ISSN 1367-3270

Klein, J. H., Connell, N. \& Meyer, E. (2005). Knowledge characteristics of communities of practice. Knowledge Management Research \& Practice, 3, pp. 106-114, ISSN 1477-8238

Lave, J. \& Wenger, E. (1991). Situated Learning: Legitimate Peripheral Participation. Cambridge University Press, ISBN 978-0521423748, New York

Leinonen, P. \& Järvelä, S. (2006). Facilitating interpersonal evaluation of knowledge in a context of distributed team collaboration. British Journal of Educational Technology, 37, 6, pp. 897-916, ISSN 1467-8535

Liebowitz, J. (1999). Knowledge Management Handbook. CRC Press, ISBN 978-1439878033, Danvers, MA.

López, A. (2009). Dossier de treball: Treball col laboratiu, visions disciplinàries. Papers. Revista sobre la societat del coneixement, 8, pp. 1-2, ISSN 1885-1541, Retrieved from <http://www.uoc.edu/uocpapers/8/dt/cat/presentacio.pdf>

McDermott, R. \& O’Dell, C. (2001). Overcoming Cultural Barriers to Knowledge Sharing. Journal of Knowledge Management, 5, 1, pp. 76-85, ISSN 1367-3270

Milton, N. (2005). Knowledge Management for teams and projects. Chandos cop, ISBN-13: 9781843341147, Oxford

Müller-Prothmann, T. (2006). Leveraging Knowledge Communication for Innovation. Framework, Methods and Applications of Social Network Analysis in Research and Development. Tesis doctoral. Retrieved from

<http://www.diss.fu-berlin.de/diss/receive/FUDISS_thesis_000000002367 >

Nonaka, I. \& Takeuchi, H. (1999). La organización creadora de conocimiento. Oxford University Press, ISBN 978-970613454, México

Petrides, L.A. \& Nguyen, L. (2006). Knowledge Management Trends: Challegenes and Opportunities for Educational Institutions. In: Knowledge Management and Higher Education. A critical analysis, A. Scott (Ed.), (pp. 21-33). Idea Group Inc, ISBN 9781591405108, Hershey

Polanyi, M. (1967). The tacit dimension. Routledge and Kegan Paul, ISBN 978-0844659992, London

Polanyi, M. (1983). Personal knowledge: towards a post-critical philosophy. Routledge and Kegan Paul, ISBN 978-0226672885, London

Ragachari, P. (2011). Knowledge sharing networks in professional complex systems. Journal of Knowledge Management, 13, 3, pp. 132-145, ISSN 1367-3270

Rao, M. (Ed.) (2005). Knowledge Management Tools and Techniques. Practitioners and Experts Evaluate KM Solutions. Elsevier, ISBN 978-0750678186, Burlington

Resnick, M. (2002). Rethinking Learning in the Digital Age. In: The global Information Technology Report: Readiness for the Networked World, G. Kirkman (Ed.) (pp.32-37). University Press, ISBN 978-0195152586, Oxford 
Rodríguez-Gómez, D. (2009). La creación y gestión del conocimiento en las organizaciones educativas: barreras y facilitadores. Tesis doctoral. Universitat Autònoma de Barcelona.

Rodríguez-Gómez, D., Armengol, C., Fuentes, M. \& Muñoz, J.L (2011). Roles y funciones en la creación y gestión del conocimiento. In: El trabajo colaborativo en red. Actores y procesos en la creación y gestión del conocimiento colectivo, J. GAIRÍN (Ed.), (pp. 161180). DaVinci, ISBN 9788492651481 , Barcelona

Saez, F., Garcia, O., Palao, J. \& Rojo, P. (2009). Capital Humano (y II): Gestión del Conocimiento e-Learning y Modelos sociotécnicos. In: Temas Básicos de Innovación tecnológica en las empresas. Retrieved from

<http://www.gsi.dit.upm.es/ fsaez/intl/indicecontenidos.html>

Sallis, E. \& Jones, G. (2002). Knowledge Management in Education: enchancing leaning and education. Kogan Page Limited, ISBN 978-0749434953, London

Schenkel, A. \& Teigland, R. (2008). Improved organizational performance through communities of practice. Journal of Knowledge Management, 12, 1, pp. 106-118, ISSN $1367-3270$

Silva, J. (2004). El rol moderador del tutor en la conferencia mediada por computador. Edutec. Revista Electrónica de Tecnología Educativa, ISSN 1135-9250, Retrieved from $<$ http:/ / edutec.rediris.es/Revelec2/revelec17/silva_16a.htm>

Smith, M. K. (2009). Communities of Practice. The encyclopedia of informal education. Retrieved from <http://www.infed.org/biblio/communities_of_practice.htm>

Smith, M.A. \& Kollock, P. (Eds.) (2003). Comunidades en el ciberespacio. Ediuoc, Comunidades en el ciberespacio, Barcelona

Sveiby, K.E. (2000). Capital intelectual. La nueva riqueza de las empresas. Cómo medir y gestionar los activos intangibles para crear valor. Gestión 2000, Máxima Laurent du Mesnil Éditeur, ISBN 9788480885454, Barcelona

Towsen, A., De Marie, S. \& Hendrickson, A.R. (1998). Virtual teams: technology and the workplace of the future. Academic of Management Executive, 12, 3, pp. 17-29, ISSN 0896-3789

Usoro, A., Sharratt, M.W., Tsui, E. \& Shekhar, S. (2007). Trust as an antecedent to knowledge sharing in virtual communities of practice. Knowledge Management Research $\mathcal{E}$ Practice, 5, pp. 199-212, ISSN 1477-8238

Ward, J. \& Peppard, J. (2002). Strategic Planning for Information Systems. Weley, ISBN 9780470841471, Chichester

Wenger, E. (2007). Communities of Practice. A brief Introduction. April 18th, 2009, Available from:

<http://www.ewenger.com/theory/communities_of_practice_intro_WRD.doc>

Wenger,E. \& Snyder, W. M. (2000). Communities of Practice: The Organizational Frontier. Harvard Business Review, 78, pp. 139-145, ISSN 0017- 8012

Wiig, K.M. (2004). People-focused Knowledge Management. How effective Decision Making leads to corporate success. Elsevier Butterworth-Heinemann, ISBN 978-0750677776, Oxford

Zang, W. \& Watts, S. (2008). Online communities as communities of practice: a case study. Journal of Knowledge Management, 12, 4, pp. 55-71, ISSN 1367-3270 


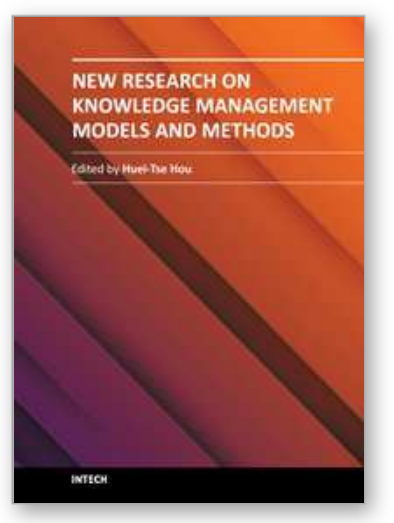

\author{
New Research on Knowledge Management Models and Methods \\ Edited by Prof. Huei Tse Hou
}

ISBN 978-953-51-0190-1

Hard cover, 426 pages

Publisher InTech

Published online 23, March, 2012

Published in print edition March, 2012

Due to the development of mobile and Web 2.0 technology, knowledge transfer, storage and retrieval have become much more rapid. In recent years, there have been more and more new and interesting findings in the research field of knowledge management. This book aims to introduce readers to the recent research topics, it is titled "New Research on Knowledge Management Models and Methods" and includes 19 chapters. Its focus is on the exploration of methods and models, covering the innovations of all knowledge management models and methods as well as deeper discussion. It is expected that this book provides relevant information about new research trends in comprehensive and novel knowledge management studies, and that it serves as an important resource for researchers, teachers and students, and for the development of practices in the knowledge management field.

\title{
How to reference
}

In order to correctly reference this scholarly work, feel free to copy and paste the following:

Joaquín Gairín, David Rodríguez-Gómez and Carme Armengol (2012). Agents and Processes in Knowledge Creation and Management in Educational Organisations, New Research on Knowledge Management Models and Methods, Prof. Huei Tse Hou (Ed.), ISBN: 978-953-51-0190-1, InTech, Available from: http://www.intechopen.com/books/new-research-on-knowledge-management-models-and-methods/agentsand-processes-in-knowledge-creation-and-management-in-educational-organisations

\section{INTECH}

open science | open minds

\author{
InTech Europe \\ University Campus STeP Ri \\ Slavka Krautzeka 83/A \\ 51000 Rijeka, Croatia \\ Phone: +385 (51) 770447 \\ Fax: +385 (51) 686166 \\ www.intechopen.com
}

\author{
InTech China \\ Unit 405, Office Block, Hotel Equatorial Shanghai \\ No.65, Yan An Road (West), Shanghai, 200040, China \\ 中国上海市延安西路65号上海国际贵都大饭店办公楼 405 单元 \\ Phone: +86-21-62489820 \\ Fax: $+86-21-62489821$
}


(C) 2012 The Author(s). Licensee IntechOpen. This is an open access article distributed under the terms of the Creative Commons Attribution 3.0 License, which permits unrestricted use, distribution, and reproduction in any medium, provided the original work is properly cited. 